\title{
Revisiting the anasynthetic spiral
}

\author{
Martin Haspelmath
}

\begin{abstract}
Grammaticalization is nowadays often seen primarily as a kind of semantic-pragmatic change, but in the $19^{\text {th }}$ century it was more typically seen in a holistic typological pespective: The idea was that synthetic languages develop from analytic languages, and that they may become analytic again. This kind of development is indeed occasionally observed in entire languages, as in the Romance languages and in Later Egyptian, but it is quite unclear whether such holistic changes are at all common. Similarly, there seems to be no good evidence that changes from agglutinative patterns to isolating patterns go through an intermediate flective or fusional stage. By contrast, there is abundant evidence for the old observation that older tightly bound constructions often get competition from new constructions based on content items, which may eventually replace the older patterns (I call this kind of process anasynthesis). Such anasynthetic changes are driven by inflationary processes that can be observed elsewhere in language and culture, not by therapeutic motivations.
\end{abstract}

\section{Overview}

Some of the best-known claimed macro-change patterns in grammatical studies, originating in typological considerations in the 19th century, are the sequences in $(1 \mathrm{a}-\mathrm{b})$ (cf. Horne 1966; Ramat 2011).

$$
\begin{aligned}
& \text { a. isolating } \rightarrow \text { agglutinative } \rightarrow \text { flective/fusional } \\
& \text { b. } \quad \text { synthetic or flective/fusional } \rightarrow \text { analytic or isolating }
\end{aligned}
$$

Even though an important part of the ideology behind these developments (value judgements favouring flective languages) was given up long ago, the awareness of these macro-change patterns is still very much with us (e.g. Hock \& Joseph 1996: 183; Dixon 1997: 42; Croft 2003: 252; Igartua 2015: 678). They are no longer seen to necessarily apply to entire languages, but they are widely regarded as an important outcome of grammaticalization processes.

In this paper, I would like to revisit these patterns and ask to what extent they can be seen as supported by evidence, and to what extent we have been able to explain them. Briefly, while I do not think that we can distinguish between agglutinative and flective types or stages (cf. Haspelmath 2009), or that there is enough evidence for saying that replacement of synthetic by analytic patterns tends to go via a stage of fusion, I do think that there is sufficient evidence to say that language patterns tend to undergo changes that can in some sense be seen as cyclic alternations between synthetic and analytic patterns, as in (2).

$$
\text { synthetic } \rightarrow \text { analytic } \rightarrow \text { synthetic }(\ldots)
$$

However, since the term synthetic generally implies the expression of multiple meanings within a single word, and there is no good way of defining "word" (Haspelmath 2011a), we cannot synchronically distinguish between synthetic and analytic patterns. But in $§ 2$ 
I will argue that it is possible to maintain some of the original intuitions if one adopts a dynamic, diachronic perspective (with ANALYTICIZATION as a crucial concept).

Moreover, the formulation in (2) might suggest a return to an earlier synthetic stage, but of course the relevant changes do not literally reverse earlier changes. For this reason, von der Gabelentz (2016[1891]) and Meillet (1921[1912]) used the term spiral, which I adopt here, calling this kind of development ANASYNTHETIC SPIRAL. More generally, an anasynthetic development (or ANASYNTHESIS) is a change in which an earlier synthetic pattern (such as the Latin future tense, e.g. canta-bi-t 'will sing') is replaced by an analytic pattern (such as the Late Latin modal construction with babere 'have', e.g. cantare babet 'has to sing'), which then undergoes various coalescence changes (Haspelmath 2011b) and in this way becomes "synthetic again".

\section{Analyticizations}

Since August Wilhelm von Schlegel's (1818: 16) discussion of grammatical changes from Latin to Romance, languages have commonly been classified as synthetic or analytic, where synthetic means that words of the language consist of several (or even many) elements, while analytic refers to languages where grammatical notions tend to be expressed by auxiliary words. Schlegel mentioned the following features of analytic languages (the French examples are added here for concreteness):

(3) a. definite articles before nouns (French la table 'the table')

b. personal pronouns before verbs (French je vois 'I see')

c. auxiliary verbs (French $j$ 'ai vu 'I have seen')

d. prepositions instead of cases (French de la table 'of the table')

e. adverbs of comparative degree (French plus grand 'bigger', lit. 'more big')

Like the distinction between isolating, agglutinative and flective types, this distinction is still very much with us, even though nowadays it tends to be used more for constructions (e.g. analytic tenses, analytic causatives, etc.) than for entire languages. Greenberg (1960) was the first to attempt to measure the degree of analyticity of a language on the basis of a corpus, and such measures of analyticity are still being applied these days (e.g. Siegel et al. 2014). ${ }^{1}$

While some of the literature of the 19th and early 20th century may have associated analytic language structure with "analytic thought" (cf. Weinrich 1963), nowadays it is universally accepted that the only difference between a synthetic pattern and an analytic pattern is that the former is a word-internal combination of formatives, while the latter involves multiple words. The distinction is thus exactly as well-founded as the notion of "word". But as Schwegler (1990) and Haspelmath (2011a) have concluded, after surveying a substantial amount of earlier literature, there is no coherent crosslinguistically applicable concept of "word" that would correspond to the intuitions that linguists have about words. It seems that these intuitions are to a large extent based on

\footnotetext{
${ }^{1}$ A derivative of the term synthetic, the notion of polysynthetic languages, has also enjoyed considerable popularity in more recent times (e.g. Evans \& Sasse 2002).
} 
our spelling habits, and these do not correspond clearly to anything in the language structure. Grammatical elements are intuitively regarded as more or less tightly linked to the host root, but this "tightness" of combination is due to a range of diverse properties that do not necessarily coincide with each other.

For instance, the English Saxon Genitive marker 's is tightly linked to its host noun in that it shows grammatically conditioned allomorphic variation (zero after nouns ending in plural -s, e.g. the boys' room, not *boys's, cf. children's room), but is loosely linked (or more clitic-like) to it in that it can occur after a postmodifying phrase (the king of Scotland's throne). Similarly, the Portuguese object person-form o 'him' is tightly linked to its host verb in that it changes its form to lo after an infinitive (vejo-o 'I see him', ve-lo 'to see him'), but it is loosely linked to it (or more clitic-like) in that it occurs in pre-verbal position under certain conditions (não o vejo 'I do not see him'). Thus, clitics and affixes cannot be generally distinguished from each other (see also Haspelmath 2015a), and neither can phrases and compound words (is Italian macchina da scrivere 'typewriter' a compound or a phrase?). This means that analytic languages (or patterns) cannot be distinguished from synthetic languages (or patterns), at least not straightforwardly. ${ }^{2}$

But Schlegel's observations about the changes from Latin to Romance were not completely unfounded. While he was mistaken (along with a large number of later linguists) in thinking that the difference between Latin and Romance is a simple synchronic typological difference, it is clear that there were a range of parallel morphosyntactic changes from Latin to French:

(4) a. Subject person-forms deriving from independent personal pronouns ( $j e, t u, i l$, etc.) have become the main expressions of subject person ( $j e$ vois 'I see', tu vois 'you see', il voit 'he sees') ${ }^{3}$, sometimes replacing subject suffixes.

b. Auxiliary verbs ('have', 'be') are used for passive voice (il est vu 'he is seen') and for Perfect (j'ai vu 'I have seen') and other tenses, some of them replacing the older forms.

c. The Latin Dative case and Genitive case were replaced by prepositions (ad and $d e$, which became French $\grave{a}$ and $d e$ ).

d. The Latin comparative in -ior (e.g. fort-ior 'stronger') was replaced by the adverb plus 'more' (plus fort 'stronger').

In each of these, an earlier pattern with tightly linked grammatical markers was replaced by a new pattern based on an earlier content word (or more concrete word, or less grammatical word). Synchronically, French il-voit 'he sees' may be just as "synthetic" as Latin vide-t 'he sees' (cf. Weinreich 1963; Miller 1992), and French plus-fort may be no more "analytic" than Latin fort-ior, but diachronically there is no doubt that that the new function items derive from earlier content items (or more concrete items).

\footnotetext{
${ }^{2}$ A reviewer asks why borderline cases, which are always there, invalidate the general distinction. The answer is that there is no good reason to assume a priori that there should be a general distinction between word-internal grammatical structure and word-external structure. If no coherent characterization of the two putative domains is possible, then one must conclude that there are no two domains to begin with, and that our spelling-based intuitions have no counterpart in spoken language.

${ }^{3}$ Note that the final consonant letter in vois/voit is not pronounced anymore.
} 
Thus, while there is no clear synchronic typology based on the synthetic/analytic distinction, there is a clear diachronic trend for older ("synthetic") patterns with strongly grammaticalized function items to be replaced sooner or later by newer ("analytic") patterns based on content (or more concrete) items. ${ }^{4}$ Thus, we can distinguish locally between analytic and synthetic patterns: When one pattern occupies the same functional slot as another pattern but is clearly younger and based on a content item, it can be regarded as "analytic relative to the earlier synthetic pattern", and we can speak about ANALYTICIZATIONS (cf. Haspelmath \& Michaelis 2017).

A crucial ingredient of this "dynamicized" view of the "synthetic/analytic" terminology is the notion of REPLACEMENT. For this reason, there is no counterpart to (3a) (articles in Romance languages) in (4). The articles are a new grammatical pattern in Romance, deriving from the less grammaticalized Latin demonstratives, but they do not replace any grammatical pattern in Latin. Thus, their rise is not a kind of analyticization, and the same is true for the English will future (which does not replace an earlier, more grammaticalized future tense in Old English) or the Mandarin Chinese object marker $b \breve{a}$ (which does not replace an earlier object marker in Classical Chinese). Now one might object that in those cases where an earlier form seems to have been "replaced", a closer look will show that in fact the new construction is used in somewhat different ways. Thus, the Slavic l-Perfect (e.g. Russian ja pisa-l 'I wrote'), which replaced the earlier Aorist (Old Church Slavonic pisax $\breve{u}$ 'I wrote'), has a somewhat different range of uses, and in some Slavic languages (especially Bulgarian), both the Perfect and the Aorist coexist. So can we speak of analyticization here? This depends on the extent to which we would be willing to say that the new form replaces the old one. In some cases, nobody would deny this (e.g. the French comparative plus fort 'more strong'), but in others one might have doubts, e.g. whether the French 'have' Perfect (j'ai vu 'I have seen, I saw') replaces the old Simple Past (je vis 'I saw'), because their range of uses is not identical. I would say that to the extent that we have doubts about the replacement relation between the Perfect and the Simple Past, we do not regard the change as an analyticization.

A reviewer asks why I keep the traditional term for the "revised concept", because he feels that "the most basic intuition" is that the contrast between analytic and synthetic has to do with "degree of morphological independence or autonomy". The answer is that I am interested in research continuity: The terms "analytic" and "synthetic" are present in the earlier literature and they will not go away, so I ask how they can be defined in such a way that the earlier insights can be preserved to a maximal extent. I have not "revised" their definition, because there was no coherent earlier definition, as far as I am aware (the intuition of "morphological independence" seems to be based entirely on our spelling habits). One may of course choose to describe the relevant developments with entirely different terms, but an important impetus of the current paper is to ask to what extent the earlier ideas are still relevant.

\footnotetext{
${ }^{4}$ Occasionally it is claimed that all grammatical markers arise in this way ("all morphemes begin their life as lexical words or stems", Givón 1999: 96). Even if this is too strong, there is little doubt that the bulk of grammatical markers in the world's languages have an origin of this type.
} 


\section{The anasynthetic spiral}

On the basis of the definition of the dynamic concepts of analyticization, as well as the diachronically relativized concepts synthetic (= to be replaced by a new analytic form) and analytic (replacing an old synthetic form), we can create the new concept anasynthetic:

\section{(5) anasynthetic change}

= a change whereby a new analytic construction arises that competes with an earlier synthetic pattern and grammaticalizes, eventually becoming the primary expression of its meaning, and thus "synthetic again"

The term anasynthetic can be seen as formed with the Greek element ana- 'again, back' (cf. ana-baptist, ana-phora), or it can be seen as a fusion of analytic and synthetic. It is a new term, but the concept is of course very old. The reason for coining a new term is that I feel that the concept is not sufficiently widely known and has not been sufficiently widely investigated, and that the older discussions of the developments have often been somewhat confused in that they did not distinguish properly between language-wide developments and constructional developments, or in that they saw a crucial role for a fusional/flective stage intermediate between the synthetic/agglutinative stage and the analytic/isolating stage (see $\S 5$ below).

Changes of this kind have often been regarded as CYCLIC (cf. Heine \& Kuteva's (2005: 165) and Igartua's (2015: 678) term morphological cycle, as well as van Gelderen 2013), but arguably, the term spiral is more appropriate, because a cyclic development implies that the change pattern leads back to exactly the same point, whereas in language, every new round of replacement brings with it substantial changes. Thus, following Gabelentz (2016[1891]) and Meillet (1921[1912]), the term spiral is used here.

Two concrete examples of changes exemplifying the anasynthetic spiral are given in (6)-(7). In each case, four idealized stages (I-IV) can be distinguished. ${ }^{5}$

(6) anasynthetic spiral of the Latin-French future tense: four stages (I-IV)

$\begin{array}{lll}\text { I } \begin{array}{l}\text { OLD CONSTRUCTION } \\ \text { canta-bi-t } \\ \text { 'will sing' }\end{array} & - & \text { NEW CONSTRUCTION } \\ \text { II canta-bi-t } & \begin{array}{l}\text { SCHEMA } \\ \text { cantare babet } \\ \text { 'has to sing' }\end{array} & \mathrm{H}-\mathrm{m}_{1} /-\mathrm{H}+\text { extra-form } \\ \text { III (canta-bi-t) } & \text { cantar ba } & \left(\mathrm{H}-\mathrm{m}_{1}\right) / \mathrm{H}+\text { marker } \\ \text { IV }- & \begin{array}{l}\text { chant-er-a } \\ \text { 'will sing' }\end{array} & -/ \mathrm{H}-\mathrm{m}_{2}\end{array}$

\footnotetext{
${ }^{5}$ It is not an accident that these four stages are very similar to the four stages distinguished by von Humboldt (1822), cf. Lehmann (2015[1982]: 2).
} 
At the first stage, only the old synthetic construction exists (the Latin future tense cantabit), which is schematized as a host $(\mathrm{H})$ with a marker $\left(-\mathrm{m}_{1}\right)$. At the second stage, a new competing construction is introduced, based on a content item (called "extraform" in the schema). At the third stage, the old construction is on its way out and the new construction is undergoing some formal reduction of the extra-form, which becomes a marker. At the fourth stage, only the new construction exists, and it has become "synthetic again", with a completely grammaticalized new marker $\left(-\mathrm{m}_{2}\right)$.

Another example comes from Classical Arabic and Maltese, where the earlier genitive suffix $-i$ was replaced by the genitive prefix $t a-$ :

(7) anasynthetic spiral of the Arabic-Maltese genitive marker: four stages (I-IV)

\begin{tabular}{|c|c|c|c|}
\hline & OLD CONSTRUCTION & NEW CONSTRUCTION & SCHEMA \\
\hline I & $\begin{array}{l}\text { al-kitaab-i } \\
\text { 'of the book' }\end{array}$ & - & $\mathrm{H}-\mathrm{m}_{1} /-$ \\
\hline II & $a l-k i t a a b-i$ & $\begin{array}{l}\text { mataaS u l-kitaab-i } \\
\text { 'possession of the book' }\end{array}$ & $\mathrm{H}-\mathrm{m}_{1} /$ extra-form $+\mathrm{H}$ \\
\hline III & (al-kiteeb) & mtaas al-kiteeb & $\left(\mathrm{H}-\mathrm{m}_{1}\right) /$ marker $+\mathrm{H}$ \\
\hline IV & $(-)$ & $\begin{array}{l}\text { ta-l-ktieb } \\
\text { 'of the book' }\end{array}$ & $-/ \mathrm{m}_{2}-\mathrm{H}$ \\
\hline
\end{tabular}

In Classical Arabic, the genitive suffix - $i$ was the only way of signaling adnominal possession, but later, a new construction making use of the content word mataai $u$ 'possession' as an extra-form came into use (see Eksell Harning 1980; KoptjevskajaTamm 1996). This was then reduced (the alternative forms bitaas and mtaas are still found in some contemporary Arabic varieties), and now it is written as a prefix in Maltese (when a definite article follows), while the old genitive has largely disappeared (though it can still be used with a few inalienable nouns).

The anasynthetic spiral can be schematized as in Figure 1: At the first schematic stage (I), there is a ("synthetic") marker $\mathrm{m}_{1}$; at the second stage (II), there is an additional, periphrastic ("extra-form") way of expressing the same notion; at the third stage (III), this has turned into an "analytic" marker, and at the fourth stage (IV), this marker has become fully grammaticalized (anasynthetic, $\mathrm{m}_{2}$ ). 


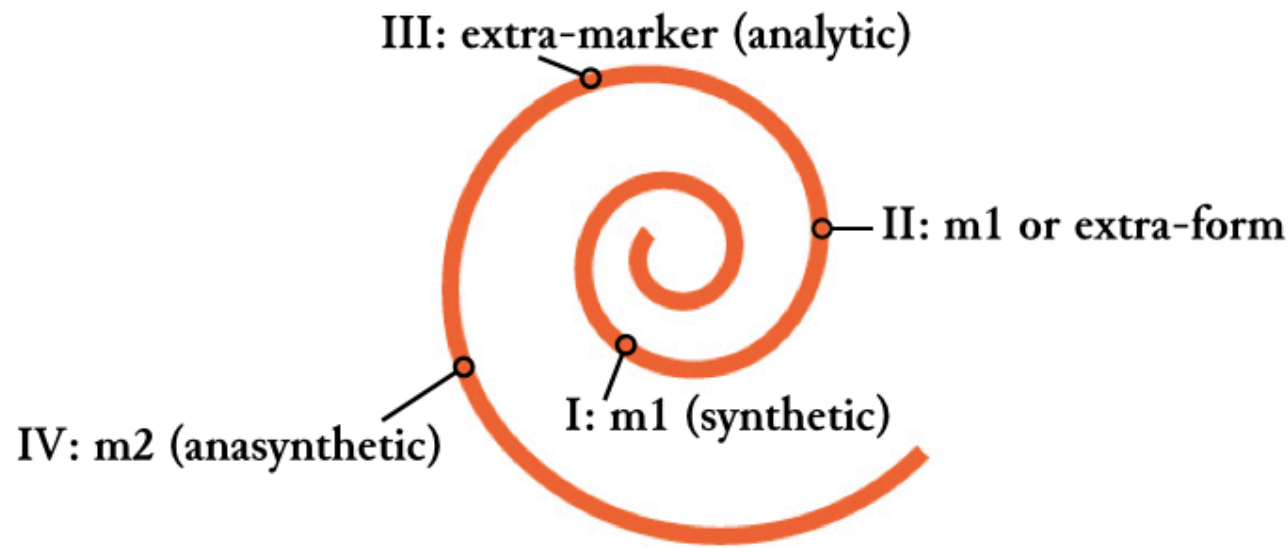

Figure 1. The anasynthetic spiral

\section{A bit of history}

Before relating the anasynthetic spiral to the more famous "isolating $\rightarrow$ agglutinative $\rightarrow$ flective $\rightarrow$ isolating" cycle, let us briefly look at the development of ideas in "evolutive typology" (as Lehmann (2015[1982]: 3) calls this approach). The three most influential works in the early 19th century were von Schlegel (1808), Bopp (1816) and von Humboldt (1822), whose speculations about the origins of morphological complexity began a long tradition (see, e.g., Horne 1970). While the idea that grammatical markers derive from earlier content items had been around even in the 18th century, the continuous tradition of typological speculation and investigation began only with Friedrich von Schlegel's discussion of the relationship between "organic" languages of the Indo-European flective type, contrasted with the "mechanic" languages of the Turkish type. For the latter, it seemed clear to everyone that their morphological patterns arose from "gluing" (agglutinating) earlier words onto host roots, so the term agglutination (coined by Wilhelm von Humboldt in 1822) came to refer both to the process of creation of new function items and their coalescence, and to a morphological type of languages. But for the Indo-European languages with their stem changes, it seemed far less clear to Schlegel and Humboldt that their inflections were due to coalescence of earlier full forms. As discussed by Stolz (1991: §4), both Schlegel and Humboldt envisaged the possibility of creating affixes "from within the root". Bopp (1816), by contrast, advocated a coalescence origin for the Indo-European person suffixes -mi, -si, -ti, as well as other affixes (cf. Lehmann (2017) for more on Bopp's agglutination theory). So for a while, the ideas of agglutinative and "de-radical" origins of inflections were in competition.

However, the idea of grammatical markers arising from full forms prevailed, not only because of the prestige of Bopp's work on Indo-European, which was evidently

\footnotetext{
${ }^{6}$ Humboldt puts it as follows: „Durch die unerforschliche Selbstthätigkeit der Sprache brechen die Suffixa aus der Wurzel hervor und dies geschieht so lange und so weit, als das schöpferische Vermögen der Sprache ausreicht. Erst wenn dies nicht mehr thätig ist, kann mechanische Anfügung antreten“ (Humboldt 1822; 1963: 494)
} 
successful in many ways, but probably also because Romance linguists were able to show conclusively that some of the Romance suffixes (especially the future tense suffixes and the adverbial suffix - ment(e)) had their origins in Latin words. Thus, von der Gabelentz (2016[1891]: 268) regarded his views on the spiral-like developments of grammatical forms as generally accepted, and Meillet's (1921[1912]) famous article that first introduced the term grammaticalization was intended as a popular account for a general audience. ${ }^{7}$ There was no similar evidence for the older idea that inflections arise from within the root, but the notion that agglutinative affixes were somehow essentially different from "true" Indo-European-style inflection lingered on.

One of the reasons why morphological typology did not generally have a good reputation since the 1870s was that it was often associated with value judgements: The Schlegels and Humboldt were clear that they regarded the "organic" patterns of IndoEuropean patterns as superior to the "mechanic" patterns of the agglutinating languages, and isolating and analytic languages were even less appreciated. At the same time, linguists were trying to arrange languages in temporal order, but this was difficult, because it seemed that morphological structure could be built up (as in pre-IndoEuropean) and disintegrate (as in Romance languages). One famous proposal for understanding the seemingly contradictory patterns was Schleicher's (1850) idea that languages built up complexity prehistorically, but are losing complexity in historical times. Another famous proposal was the opposite idea (Jespersen 1894) that while synthetic complexity was old and poorly designed, analytic simplicity constituted progress (cf. McMahon (1994: §12.2) for an accessible account of these discussions).

These views of linear developments were then superseded by the modern view that developments are basically cyclic, and that morphological patterns do not reflect cultural progress or decay. The reason why von der Gabelentz (1891) and Meillet (1912) are still widely cited is that their views hardly differ from contemporary views.

Nevertheless, there is one aspect of the earlier stage of morphological typology that is still widely assumed as correct: the idea that the development from agglutinative to analytic/isolating (patterns or languages) goes via a stage of "flection" or "fusion":

$$
\text { isolating } \rightarrow \text { agglutinative/synthetic } \rightarrow \text { flective/fusional } \rightarrow \text { analytic/isolating }
$$

This will be discussed in the next section.

\footnotetext{
${ }^{7}$ Nevertheless, the neogrammarians did not focus on grammaticalization, and they tended to prefer to look for analogy-based origins of morphological elements. Jespersen (1922: Chapter 19) even attacked the agglutination theory, and for several decades it was not widely pursued. (Tauli (1958) and Hodge (1970) were non-mainstream and not influential during their times; interest in grammaticalization became widespread again only with Givón 1971.)

${ }^{8}$ While the term agglutinative (German agglutinierend) has no competitors, the literature contains both the terms flective and fusional (the latter apparently first used by Sapir 1921). No clear distinction between them seems to have been drawn by anyone, and perhaps the main reason for introducing fusional was that inflection had come to acquire a more general sense by the 20th century, referring not only to IndoEuropean-style fusional inflection. The term flective (Plank 1986, for German flektierend) has the advantage of being unique (in contrast to inflectional, inflecting, etc.) and of preserving the continuity with the long Humboldtian tradition. I use both terms interchangeably.
} 


\section{From agglutination to isolation via fusion?}

One widespread assumption, seemingly confirmed by the history of Romance and Germanic languages, is that the change from earlier synthetic patterns to new analytic patterns was primarily due to phonetic erosion. Variants of this view are still widely held, and the difference between agglutinative and fusional patterns might plausibly be related to sound change, so it is not so surprising that we still encounter the old idea that the change from the agglutinative stage to the isolating/analytic stage generally passes through a fusional/flective stage, as in (8). This development, schematized in Figure 2, is called agglutination-fusion-isolation cycle here. The cycle is presented and discussed at some length in Dixon (1994: 182-185), Crowley \& Bowern (2010: 221225) and Igartua (2015: 678), and it is also mentioned without criticism by Hock \& Joseph (1996: 183), Dixon (1997: 42), and Croft (2003: 252).

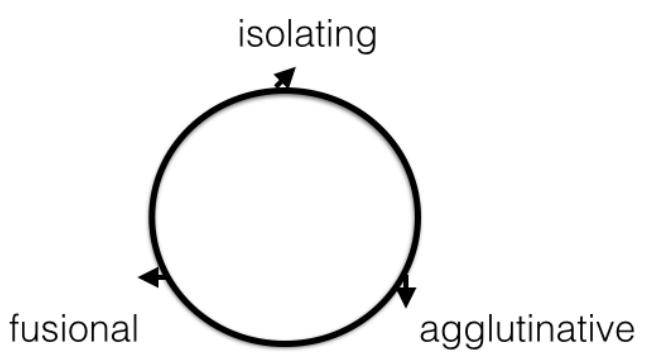

Figure 2: The agglutination-fusion-isolation cycle

But what is the evidence for the intermediate position of fusion between agglutination and isolation? I have not been able to find much discussion of this. In their influential textbook, Hock \& Joseph (1996: 181) simply say:

"In agglutinating languages, the affixes retain their phonetic identity to such an extent that it is easy to tell where one affix begins and the next one ends. If sound change obscures the boundaries between affixes and brings about their amalgamation, the result is an inflectional language."

Likewise, Dixon (1994: 184) states that "from an agglutinative profile, the operation of ... phonological change will effectively preserve the same morphological elements but fuse their realisations".

But do the properties of flective languages really result from sound change? As discussed in Haspelmath (2009), the three main distinctive features of flective patterns are generally thought to be (i) cumulative exponence (e.g. suffixes like Russian -ov for genitive + plural), (ii) the existence of stem alternations (e.g. English sing/sang), and (iii) the existence of affix alternations (e.g. Russian dative forms in $-u /-e /-i$ depending on the inflection class) (see also Igartua (2015: §2.2) for a similar account). It seems that nobody has made a strong case that flective patterns result from phonological reductions, but many people have made this assumption. I cannot examine the question in detail here, but I will now give some reasons why I have very little confidence in the truth of the claim.

Cumulative exponence as a feature of flective languages is easy to illustrate from older Indo-European languages, but it actually seems to be quite rare, apart from 
person-number cumulation (which is frequent not only in bound person markers, but also in independent personal pronouns, cf. Daniel 2005; since it is extremely frequent everywhere, it is not discussed further here). In particular, the kind of number-case cumulation that is found widely in the older Indo-European languages and that contrasts so strikingly with the separative exponence found in non-Indo-European languages (e.g. Russian dom-óv 'of houses', contrasting with Turkish ev-ler-in [housePL-GEN], Igartua 2015: 683) seems to be very rare in the world's languages. Be that as it may, what is the evidence that its origins may have to do with sound changes? There are many speculative ideas about the origin of the older Indo-European plural endings $\left({ }^{*}-e s,{ }^{*}-n s,{ }^{*}-o m,{ }^{*}-s u{ }^{*}-b^{h} i\right.$, cf. Clackson 2007: 99) but as far as I know, only one of the endings has a possible origin in an earlier separative (i.e. agglutinative) combination, namely the accusative plural suffix $-n s$, which has been claimed to go back to $-m-s$ (accusative $-m$ plus plural $-s$ ). But this hypothesis does not have much plausibility, because it would show a plural suffix outside a case suffix, a pattern that is virtually unattested in other languages (cf. Greenberg's (1963) Universal 39). Thus, almost all instances of case-number cumulation in Indo-European go back to the protolanguage, and their origin is obscure.

Igartua (2015: §3) claims that Estonian and Basque show the incipient development of fusion (flective patterns) due to sound change, but the evidence for this is actually very slim. He contrasts Estonian and Finnish number-case paradigms and shows that Estonian has somewhat more cumulation, as seen in the partial paradigms in (9) (Estonian lipp 'flag', Finnish lippu 'flag').

$\begin{array}{lllll} & \text { Finnish } & & \text { Estonian } & \\ & \text { SG } & \text { PL } & \text { SG } & \text { PL } \\ \text { nominative } & \text { lippu } & \text { lipu-t } & \text { lipp } & \text { lipu-d } \\ \text { genitive } & \text { lipu-n } & \text { lipu-j-en } & \text { lip-u } & \text { lippu-de } \\ \text { partitive 1 } & \text { lippu-a } & \text { lippu-j-a } & \text { lipp-u } & \text { lippu-sid } \\ \text { partitive 2 } & - & - & - & l i p p-e \\ \text { illative 1 } & \text { lippu-un } & \text { lippu-i-hin } & \text { lipu-sse } & \text { lipu-de-sse } \\ \text { illative 2 } & - & - & l i p p-u & - \\ \text { inessive } & \text { lipu-ssa } & \text { lipu-i-ssa } & \text { lipu-s } & \text { lipu-de-s } \\ \text { adessive } & \text { lipu-lla } & \text { lipu-i-lla } & \text { lipu-l } & \text { lippu-de-l }\end{array}$

It is true that Estonian has two forms that are clearly cumulative and which do not have cumulative counterparts in Finnish (partitive 1 plural lippu-sid, partitive 2 plural lipp-e), but the first of these does not seem to result from sound change, and the Finnish paradigm, too, shows a striking instance of cumulation, namely the nominative plural suffix $-t$. In fact, the biggest difference between the two languages is that the dental stop has been extended from the nominative to most of the other cases (lipudesse, lipudes, lippudel), thus actually eliminating some cumulation. Thus, this is not a good example of phonetically induced cumulation, and neither is the Basque paradigm which Igartua also discusses (this shows quite a bit of allomorphy, whose origins seem obscure, and only one case of cumulation, the absolutive plural suffix $-a k$, which is not due to phonetic changes either). 
Indo-European languages also sometimes show person-number-tense cumulation, as in the French Passé Simple illustrated in (10), and compared with the Latin Perfect, from which it derives.

$\begin{array}{lll} & \text { Latin } & \text { French } \\ \text { 1SG } & \text { cantavi } & \text { chantai } \\ \text { 2SG } & \text { cantavisti } & \text { chantas } \\ \text { 3SG } & \text { cantavit } & \text { chanta } \\ \text { 1PL } & \text { cantavimus } & \text { chantâmes } \\ \text { 2PL } & \text { cantavistis } & \text { chantâtes } \\ \text { 3PL } & \text { cantaverunt } & \text { chantèrent }\end{array}$

It is true that the Latin tense suffix $-v$ disappeared in French, and in this sense the 1SG form chantai (< cantavi) and the 3PL form chantèrent (< cantaverunt) are now more cumulative. But overall it is hard to say that the new paradigm is more cumulative, because the French paradigm has a new tense marker $-a /-\dot{e}$, and clearly segmentable person markers at least in the plural. ${ }^{9}$ In Latin, by contrast, four of the six paradigm forms have multiple exponence, with cumulative person forms -i, -isti, -istis, and -erunt. Thus, the French paradigm can even be said to be somewhat more separative than the Latin paradigm. And the one paradigm in French verb inflection which clearly shows substantial cumulation, the future tense (with future suffix $-r$ plus future-specific person forms -ai/-as/-a/-ont/-ez/-ont) did not arise via sound change, but via coalescence (as seen earlier in (6)).

While cumulation does not seem to arise commonly via sound change, it is easier to provide examples of stem alternations and affix alternations (agglutination criteria (ii) and (iii) above) that result from phonological developments. In fact, phonologically conditioned alternations are by no means restricted to or even characteristic of "flective" languages and are very common in all types of languages, including those traditionally called agglutinative. For example, Hagège (1990: 299-300) notes that Turkish has stem consonant alternations in nominative/accusative forms such as sebep/sebeb-i 'cause', kelebek/kelebeğ-i 'butterfly', and Kannada has affix alternations as in katte/katte-ge (nominative/dative singular of 'donkey') versus katte-galu/katte-gal-ige (nominative/dative plural). These are clearly phonologically conditioned and plausibly due to an earlier sound change. But for the characteristic inflectional classes of IndoEuropean languages (which involve affix suppletion, not just alternation), e.g. the Latin $o^{-}, a^{-}$and $i$-declension, it is much less clear that the different affixes have anything to do with sound changes. Why does the genitive of populus end in $-i$ (popul-i of the people'), while the genitive of rex 'king' ends in -is (reg-is)? Why does the dative plural of populus end in -is (popul-is) and the dative plural of rex in -ibus (reg-ibus)? Nobody seems to know, and phonological change does not seem to be the main reason.

Perhaps the most striking phenomenon of Sanskrit and the Germanic languages that Friedrich Schlegel and Jakob Grimm were deeply impressed by two centuries ago are the vowel changes (called ablaut by Grimm), especially in the verbal system, which

\footnotetext{
${ }_{9}$ The development of the second person singular form chantas can only be explained by analogical leveling, not by sound change.
} 
seemed to go back to a vowel-change system in the protolanguage (apparently corresponding to more residual vowel changes in Greek and Latin, cf. Greek légo 'say' and lógos 'word', Latin tego 'cover' and toga 'covering piece of cloth'). In the meantime, there have been many attempts to reduce these vowel alternations to earlier phonological changes, but especially the elo alternation has resisted attempts at explanation (cf. Clackson 2007: 72-73). The origins of the even more striking vowel alternations in the Semitic languages are equally obscure.

Thus, contrary to a widespread presumption, the most salient aspects of flective languages do not seem to go back to sound changes, and their origins are typically unknown. More generally, we do not know how it is that robust inflectional patterns with cumulative and suppletive affixes arise. I have not seen good evidence that flective patterns tend to be intermediate between agglutinative and isolating patterns.

It thus appears that the idea of an agglutination-fusion-isolation cycle is a remnant of the 19th century, when it was widely assumed that flective languages are a higher, more advanced development from the more primitive, less perfect agglutinative languages. It is time to abandon that view (or to make a serious effort to come up with actual evidence that supports it).

By contrast, the anasynthetic spiral, and the original idea of bound forms arising from earlier free forms, of function items going back to content items, has stood the test of time and has been confirmed by many different examples showing basically the same pattern as the examples in (6) and (7).

\section{Remarks on holistic anasynthesis}

The recognition that it may not be entire language systems, but particular constructions, that develop in systematic ways has been around for a long time time (e.g. Sapir 1921: 128). This is a retreat from the much stronger, earlier hypothesis that it is entire language systems that develop in coherent ways - apparently a necessary retreat. By and large, languages do not seem to be governed by large-scale regularities, and the search for "macroparameters" or "great underlying ground-plans" has proven largely futile so far (Haspelmath 2008). As van Gelderen (2013: 248) puts it: "Macrocycles" have remained controversial.

Nevertheless, it has sometimes been suggested that entire languages can shift from being largely synthetic to largely analytic or vice versa. The most striking development is that of Egyptian-Coptic, as described by Hintze (1947) and famously by Hodge (1970) (cf. also Reintges 2013; Haspelmath 2015b: §2.1). Egyptian-Coptic is attested over more than three millennia, and even though the hieroglyphic script does not represent the vowels, it is quite clear that a fair number of constructions with postposed function items were replaced by new constructions with preposed function items. In the examples in (11), the symbol $\gg$ means 'is replaced by', and the symbol > means 'turns into'. The left-hand example represents Earlier Egyptian, and the right-hand example represents Coptic (which was written in Greek script including vowel letters). Note that the new preposed markers are generally quite different from the earlier postposed markers (except for (11c)). 
(11) a. postposed demonstrative $\gg$ preposed demonstrative pei-/tei-

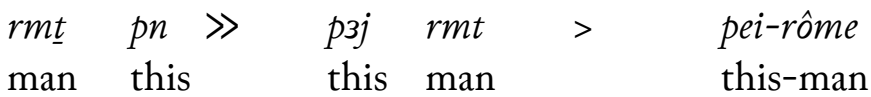

'this man'

b. $\quad$ preposed demonstrative $>$ prefixed definite article $p-/ t-$

p3 rmt $>\quad p 3 r m t>p$-rôme

'this man' 'the man' 'the man'

c. numeral 'one' > prefixed indefinite article ou-

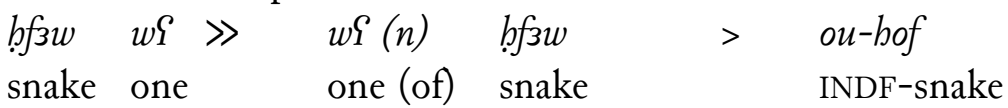

d. ordinal numeral suffix $-n w \gg$ prefix $m e b-$

$b m t-n w \gg m b-b$ mt $>$ meb-šomnt

three-ORD fill-three ORD-three

'third'

e. suffixed possessive pronoun $\gg$ prefixed possessive pronoun (following the article)

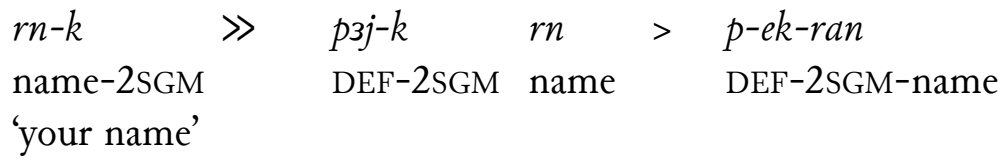

f. postverbal-subject construction $\gg$ pre-subject-TAM construction

$s \underline{d} m-n-f \quad \gg \quad j r-f \quad s d m>a-f-s \hat{t} t m$

hear-PRF-3SGM do-3SGM hear PRET-3SGM-hear

'he heard'

g. Stative construction with agreement $>$ Stative without agreement

$X$ st $w \underline{d} 3-t j \quad>\quad s t w \underline{d} 3>s-o u o j$

$\mathrm{X}$ she whole.STAT-3SGF she whole 3SGF-whole.STAT

'she is whole' ( $\mathrm{X}=$ some particle)

h. synthetic suffixed passive $\gg$ passive-like construction with 3PL person form

$s \underline{d} m-w-f \quad \gg \quad a-u-s o t m-f$

hear-PASS-3SGM PRET-3PL-hear-3SGM

'he was heard' 'he was heard' ("they heard him")

i. periphrastic construction $>$ subject-verb construction
$X \quad s w$ br $\quad$ d $d m$
f-sôtm
he on hear
3SGM-hear
'he is hearing' $(\mathrm{X}=$ some particle)
'he is hearing, he hears' 


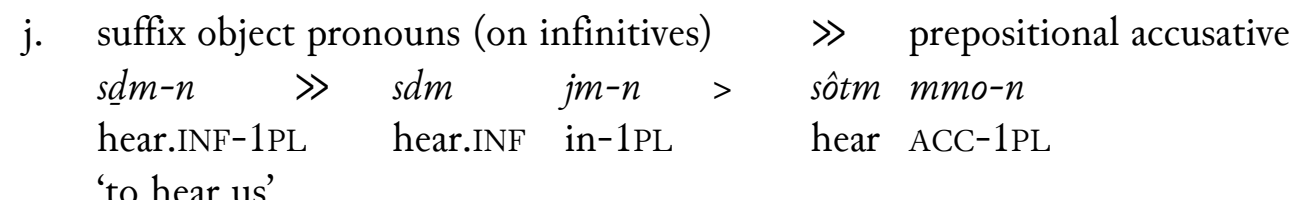

It thus appears that the Egyptian-Coptic language underwent a wholesale change from a suffixing or function-item-postposing macro-pattern to a prefixing or prepositing macro-pattern. This development is fascinating, as there is no strong reason why the changes should be connected in this way. Languages clearly do not have to change their patterns in such a concerted way, but it seems difficult to believe that these changes should be entirely accidental. ${ }^{10}$

A similar macro-pattern has been described for the development of Romance languages, and more specifically French, by Baldinger (1968) (see also the discussion in Jacob 1990). Baldinger notes that quite a few function items in French are preposed to their hosts, whereas the corresponding Latin items occur after their hosts. This goes beyond the old observations by August Wilhelm von Schlegel in that Baldinger highlights the change in the ordering of the elements (in the spirit of Greenberg 1963).

(12) a. definiteness (le, la)

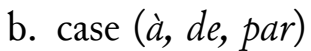

c. number (definite articles: le/les, la/les: possessive determiners: mon/mes)

d. gender (le/la, un/une)

e. comparison (plus grand)

f. compound tenses (j'ai chanté, etc.)

g. relative pronoun (qui chante) (replacing the Latin participle)

h. subject person forms $(j e, t u, i l, \ldots)$

i. question particle (est-ce que)

Again it seems difficult to believe that these changes should be unconnected, but how exactly they might be connected is not clear.

If there were a tendency for entire languages to lose their old synthetic forms and acquire new ones, one might expect to find larger language families where different branches differ in that some preserve the old synthetic forms, while others have lost them and replaced by entirely new forms (whether with a consistently different order, as in Coptic and French, or with no ordering regularities). However, there are not many candidates of such changes, and they all appear to be controversial. Nichols (1996: 63) mentions Austroasiatic, Niger-Congo, and Trans-Himalayan as possible cases. In the following paragraphs, I make a few more comments on these three families, without offering a clear conclusion.

For the Austroasiatic family, Donegan \& Stampe (2004) claim that they were originally analytic and head-initial, like the Mon-Khmer languages in the east, whereas the synthetic and head-final patterns of Munda languages in the west represent an innovation. However, according to Zide \& Anderson (2001), Proto-Austroasiatic

\footnotetext{
${ }^{10}$ Note that there is no claimed connection between the analyticization and the change in the position of the forms. The latter is puzzling, though a parallel has been found in Romance languages, as discussed immediately below.
} 
morphology was more like Munda morphology, and the Mon-Khmer languages adopted the areal characteristics of the other Mainland Southeast Asian languages (TaiKadai, Hmong-Mien, Trans-Himalayan).

In the Niger-Congo (or Atlantic-Congo) language family, one sees a striking contrast between more synthetic languages like the well-known Bantu languages, and more analytic languages (often without gender categories) like the Kwa, Defoid and Igboid languages. There are also more analytic Bantu languages, especially those of the Bantu A subgroup in the northwest, and there has been an interesting recent debate between Güldemann (2011) and Hyman (2011). While Güldemann claims that ProtoBantu was more like the (analytic) Kwa languages, in line with the general features of the Macro-Sudan belt, Hyman thinks that the analytic northwestern Bantu languages are innovative and that Proto-Bantu was like the better-known Zulu or Swahili type. ${ }^{11}$ Similarly, Good (2012) considers the Kwa-type noun patterns as secondary compared to the more elaborate Bantu type.

Finally, for the Trans-Himalayan family (also called Sino-Tibetan), Scott DeLancey has recently published a series of papers in which he claims that some of the languages retain old synthetic patterns, while others have innovative synthetic patterns (e.g. DeLancey 2015). Thus, Kiranti and Gyalrongic are two subfamilies spoken in different regions which have very similar and rather idiosyncratic person index paradigms, which are therefore reconstructed for the protolanguage. Sinitic and Tibetic are two families that do not show person indexing at all, while Kuki-Chin languages have clearly innovative, anasynthetic person indexing paradigms.

Thus, even though not only the changes we see in Romance (and Germanic) languages, but also the really striking changes observed in Egyptian-Coptic may seem to support the idea of holistic anasynthesis, there are not many other clear cases of macroanasynthesis. This may be because we do not have the kind of good diachronic data that is available for Egyptian-Coptic and Latin-Romance, or it may be due to the fact that such changes are genuinely uncommon. One suggestion that points in this direction is the proposal that large-scale changes of grammatical patterns occur only when massive bilingualism disrupts the development of a language, as has happened in the Western Roman Empire, where a large number of people learned Latin as a foreign language (cf. McWhorter 2007). The same must have happened in Egyptian-Coptic (where the large number of foreign labourers in Egypt may have been a factor in unusual language change), and quite possibly elsewhere (see also DeLancey 2014).

\section{What drives the anasynthetic spiral?}

Before concluding this paper, I would like to revisit also the explanation for the driving force behind the anasynthetic spiral. I will contrast three explanations, which I call (i)

\footnotetext{
11 "There has been plenty of time for Proto-Bantu (and even more time for Proto-Niger-Congo) to cycle back and forth, grammaticalizing full words as inflectional proclitics and prefixes, losing them, and creating them once more. ... [Dating] may not be easy to do, given the cyclicity. We all seem to agree that Proto-Bantu came from an earlier analytic stage - the question, however, is whether Basaá, Tunen etc. represent that unchanged stage, or whether they are completing the cycle: analytic > agglutinative > analytic. I maintain that the latter is the case." (Hyman 2011: 24)
} 
therapeutic periphrasis ("periphrasis saves"), (ii) extravagance and inflation, and (iii) redundancy regulation. I will argue that the second explanation must be the correct one.

The best-known explanation is the therapeutic explanation, which assumes that older grammatical markers were weakened by phonological reduction and then had to be replaced by new periphrastic forms in order to preserve the functionality of the language. This explanation was commonly assumed throughout the 19th century, and also widely in the 20th century. In Georg von der Gabelentz's (1891[2016: 269]) famous characterization of the anasynthetic spiral, the ideas of "wearing off" of older forms and compensatory periphrasis are very clear:

"Die Affixe verschleifen sich, verschwinden am Ende spurlos; ihre Funktionen aber oder ähnliche drängen wieder nach Ausdruck. Diesen Ausdruck erhalten sie, nach der Methode der isolierenden Sprachen, durch Wortstellung oder verdeutlichende Wörter. Letztere unterliegen wiederum mit der Zeit dem Agglutinationsprozesse, dem Verschliffe und Schwunde, und derweile bereitet sich für das Verderbende neuer Ersatz vor: periphrastische Ausdrücke werden bevorzugt." 12

This view was also at the basis of Jespersen's (1917: 4) discussion of the cyclic developments that have later become known as "Jespersen's Cycle":

"The history of negative expressions in various languages makes us witness the following curious fluctuation: the original negative adverb is first weakened, then found insufficient and therefore strengthened, generally through some additional word, and this in turn may be felt as the negative proper and may then in the course of time be subject to the same development as the original word."

More recently, the therapeutic view was explicitly defended by Geurts (2000) (a response to Haspelmath 1999; see my reply in Haspelmath 2000). ${ }^{13}$

While the idea of therapeutic periphrasis hypothesizes that phonological reduction is the driving force, the "extravagance and inflation" view sees reduction as the consequence of semantic change from content meaning to grammatical meaning, which leads to frequent use, in a pragmatically governed inflationary process: Novel forms are introduced for their special extravagant effect, but when they are copied and become more frequent, this effect weakens, just like the value of a currency goes down when too many banknotes are in circulation (Dahl 2001; 2004: 121-125 calls this "rhetorical devaluation"). Thus, the two first accounts can be seen as making opposite claims:

a. reduction first $\rightarrow$ periphrasis saves or repairs

\footnotetext{
12 "The affixes are worn down, disappear without a trace at the end; their functions or similar ones demand expression again. They receive this expression, after the manner of the isolating languages, through word order or clarifying words. These are again gradually subject to the agglutination process, to wearing down and to loss, and in the meantime a replacement is being prepared for what perished: periphrastic expressions are preferred."

13 "Then $\beta$ gets the upper hand, wears down due to the general drive towards efficiency of expression, until it is weakened to the point where it has to be replaced by some $\gamma$." (Geurts 2000: 783)
} 
b. extravagance/periphrasis $\rightarrow$ inflation and reduction

There are five reasons why the first explanation does not work and the second explanation must be correct:

First, it is implausible that phonological reduction would lead to dysfunctional patterns. Even though the metaphor of "wearing off" is often used for phonological change, sounds are not like material objects in that they lose their substance due to frequent use.

Second, the loss of older categories and their replacement by new forms also happens when there is little or no phonological reduction. Thus, in the Balkan Slavic languages (Bulgarian and Macedonian), the older Slavic case system has been drastically reduced and replaced by prepositions, even though the phonological development did not differ noticeably from that of other Slavic languages. For Jespersen's Cycle, Kiparsky \& Condoravdi (2006) find that in their data, phonetic reduction played no role. And for eastern Asian languages, it has been claimed explicitly that phonological reduction is not part of grammaticalization processes (Bisang 2004). A reviewer also points out that polysynthetic languages, which express many categories in the verb, may still show rich periphrastic patterns.

Third, grammaticalization not only "restores" grammatical categories that were lost, but often creates completely novel categories by the same mechanisms, such as the definite article in Romance languages. Such developments cannot be explained by reduction. (However, strictly speaking these cases do not fall under anasynthesis, as defined in $\S 2$ above.)

Fourth, new grammatical categories may arise even when the old categories do not disappear (right away). For example, both English and French have a traditional future (I will writelj'écrirai), but this has not prevented the grammaticalization of another future, based on 'go', that is subtly different in meaning (I'm gonna writelje vais écrire). In many northern Italian varieties, the subject clitics are grammaticalized as agreement markers, although the agreement suffixes inherited from Latin are still largely intact. Bulgarian has preserved the old Imperfect/Aorist (=imperfective past/perfective past) distinction of early Indo-European, but this has not stopped it from grammaticalizing the new perfective/imperfective opposition as found in other Slavic languages. Again, these developments do not fall under anasynthesis as defined earlier, but the changes are in no way different from the changes that replace earlier categories.

Fifth, we find quite similar developments in lexical change. Speakers occasionally introduce elaborate, vivid ("extravagant") expressions for relatively banal contents in order to be noticed, or in other words because of the greater salience associated with the novel expressions. A similar explanation can be given for many cases of lexical-semantic change, e.g. developments from 'speak' to 'say' (e.g. Polish mówic') or from 'walk' to 'go' (e.g. Italian andare), or from 'intact' to 'whole' (Latin integer > French entier). These can be accounted for by the inflationary model, but not by the periphrasis saves model.

But what about the third explanation, "redundancy regulation"? This explanation was advanced by Lüdtke $(1980 ; 1986)$ and taken up by Keller (1994: 104-108) as well as Haspelmath (1998). This explanation starts out from the observation that language use varies both along the phonetic dimension and the morphosyntactic dimension (for the latter, see also Croft 2010), and speakers have a whole range of reduced or expanded 
options at their disposal for the purposes of "redundancy regulation". According to these authors, an asymmetry consists in the fact that variation along the phonetic dimension is open toward the reduction pole (phonetic reduction can be indefinite) and closed toward the expansion pole (we do not expand phonetically, i.e. we do not speak more clearly than fully clearly). By contrast, variation along the morphosyntactic dimension is said to be open toward the expansion pole (verbosity can be indefinite, i.e. we can always add further explanatory words and phrases) but closed toward the reduction pole (we do not reduce morphosyntactically, i.e. we do not simply omit affixes or function words). Hence, the range of reduced and expanded options continually changes in the direction of morphosyntactically expanded forms.

But as Campbell (2001: 136) noted correctly, it is not quite true that phonetic expansion is impossible, because expansive sound changes do occur (lengthening, strengthening, epenthesis, and so on). Moreover, this explanation, too, relies on the idea that phonologically weak reduced forms disappear on their own, and on the idea of "compensatory" morphosyntactic enrichment. This view neglects the fact that there are a lot of possibilities for repairing older categories if they become indistinct due to sound change. For example, the singular-plural distinction was preserved in English, even though most of the Old English plurals were no longer distinct from the singulars after final vowels and nasals were dropped. What happened was that the one plural ending that was still distinct phonologically (the $-s$ plural) spread over (almost) the entire class of nouns. There was no need to introduce a completely new plural form based on a content item, along the lines of Seychelles Creole bann (from French bande 'group') or Tok Pisin ol (from English all) (cf. Michaelis \& Haspelmath 2017).

Thus, I conclude that the best explanation for the anasynthetic spiral is the extravagance and inflation model of grammaticalization.

\section{Conclusion}

The most important idea of 19th century evolutive typology that has survived into the 21st century is the hypothesis that many or most grammatical markers derive from earlier content items, and that the re-creation of grammatical patterns and systems on the basis of content items (or more concrete items) is a common process in language change. When earlier forms get competition from newer constructions based on content items, we can speak about analyticizations, and when these constructions become the most grammaticalized pattern in the language, we can speak about anasynthesis. Such developments can often be seen at the level of particular constructions, and sometimes perhaps at the level of entire language systems, as in Egyptian-Coptic.

Another idea that is still widely found but that has not been substantiated is the claim that there is generally a fusional or flective stage intermediate between the older agglutinative synthetic stage and the analytic stage. Flective patterns (cumulative exponence, stem alternations, affix alternations) do not seem to originate in sound changes - the origins of the most robust patterns of this kind seem to be obscure.

The driving force behind the grammaticalization changes that are reflected in anasynthetic patterns is best described as extravagance with inflation, i.e. the semantic developments precede any formal developments (as also emphasized by Heine 2017, in 
this volume). The older idea that anasynthetic changes are a reaction to the destructive force of sound changes is not well-motivated.

Finally, readers should be aware that the judgements expressed in this paper about the value of particular ideas and approaches are entirely based on experience and intuition. I did not bring any quantitative evidence to bear on the competing hypotheses. Perhaps this is a development that future research of macro-change patterns will take: Linguists may develop cross-linguistic databases of comparable diachronic developments in different languages from different parts of the world, and then we will be more confident about our results. However, just as the bold speculations of the Schlegels, Humboldt, Bopp, Schleicher and Jespersen contributed to our knowledge by inspiring much further research, I think that speculative big-picture ideas still have a valuable role in our times.

\section{References}

Baldinger, Kurt. 1968. Post- und Prädeterminierung im Französischen. In: Baldinger, Kurt (ed.) Festschrift Walther von Wartburg zum 80. Geburtstag, 87-106. Tübingen.

Bisang, Walter. 2004. Grammaticalization without coevolution of form and meaning: The case of tense-aspect-modality in East and mainland Southeast Asia. In: Walter Bisang, Nikolaus P. Himmelmann, Björn Wiemer (eds.), What makes grammaticalization? - a look from its fringes and its components, 109-138. Berlin: Mouton de Gruyter.

Bopp, Franz. 1816. Uber das Conjugationssystem der Sanskritsprache. Frankfurt am Main: Andreäischen.

Campbell, Lyle. 2001. What's wrong with grammaticalization? Language Sciences 23. 113-161.

Clackson, James. 2007. Indo-European linguistics: An introduction. Cambridge: Cambridge University Press.

Croft, William. 2003. Typology and universals. Cambridge: Cambridge University Press.

Croft, William. 2010. The origins of grammaticalization in the verbalization of experience. Linguistics 48(1). 1-48.

Crowley, Terry \& Claire Bowern. 2010. An introduction to bistorical linguistics. Oxford: Oxford University Press.

Dahl, Östen. 2001. Inflationary effects in language and elsewhere. In Joan L. Bybee \& Paul J. Hopper (eds.), Frequency and the emergence of linguistic structure, 471-480. Amsterdam: Benjamins.

Dahl, Östen. 2004. The growth and maintenance of linguistic complexity. Amsterdam: Benjamins.

Daniel, Michael. 2005. Plurality in independent personal pronouns. In Martin Haspelmath, Matthew S. Dryer, David Gil \& Bernard Comrie (eds.), The world atlas of language structures. Oxford: Oxford University Press.

DeLancey, Scott. 2014. Sociolinguistic typology in North East India: A tale of two branches. Journal of South Asian Languages and Linguistics 1(1). 59-82.

DeLancey, Scott. 2015. The historical dynamics of morphological complexity in TransHimalayan. Linguistic Discovery 13(2). 60-79.

Dixon, R.M.W. 1994. Ergativity. Cambridge: Cambridge University Press.

Dixon, R.M.W. 1997. The rise and fall of languages. Cambridge: Cambridge University Press.

Donegan, Patricia \& David Stampe. 2004. Rhythm and the synthetic drift of Munda. The Yearbook of South Asian languages and linguistics 7. 3-36.

Eksell, Kerstin. 1980. The analytic genitive in the modern Arabic dialects. (Acta Universitatis Gothoburgensis). Gothenburg: Gothenburg University. 
Evans, Nicholas \& Hans-Jürgen Sasse (eds.). 2002. Problems of polysynthesis. Berlin: Akademie Verlag.

Gabelentz, Georg von der. 1901. Die Sprachwissenschaft, ibre Aufgaben, Methoden und bisherigen Ergebnisse. 2. Auflage. Leipzig: C. H. Tauchnitz.

Gelderen, Elly. 2013. The linguistic cycle and the language faculty. Language and Linguistics Compass 7(4). 233-250.

Geurts, Bart. 2000. Explaining grammaticalization (the standard way). Linguistics 38(4). 781788.

Givón, T. 1999. Internal reconstruction, on its own. In Edgar C. Polomé \& Carol F. Justus (eds.), Language change and typological variation: In honor of Winfred P. Lebmann on the occasion of bis 83rd birthday, volume I: Language change and phonology, 86-130.

Washington: Institute for the Study of Man.

Givón, Talmy. 1971. Historical syntax and synchronic morphology: An archaeologist's field trip. Chicago Linguistic Society 7. 394-415.

Good, Jeff. 2012. How to become a "Kwa" noun. Morphology 22(2). 293-335.

Greenberg, Joseph H. 1960. A quantitative approach to the morphological typology of language. International journal of American Linguistics 26(3). 178-194.

Greenberg, Joseph H. 1963. Some universals of grammar with particular reference to the order of meaningful elements. In Joseph H. Greenberg (ed.), Universals of language, 73-113. Cambridge, MA: MIT Press.

Güldemann, Tom. 2011. Proto-Bantu and Proto-Niger-Congo: Macro-areal typology and linguistic reconstruction. In Osamu Hieda, Christa König \& Hirosi Nakagawa (eds.), Geographical typology and linguistic areas: With special reference to Africa. Amsterdam: Benjamins.

Hagège, Claude. 1990. Do the classical morphological types have clear-cut limits? Contemporary morphology, ed. by Wolfgang U. Dressler, Hans C. Luschützky, Oskar E. Pfeiffer, and John R. Rennison, 297-308. Berlin: Mouton de Gruyter.

Haspelmath, Martin \& Susanne Maria Michaelis. 2017. Analytic and synthetic: Typological change in varieties of European languages. In Isabelle Buchstaller \& Beat Siebenhaar (eds.), Language variation - European perspectives VI: Selected papers from the 8th International Conference on Language Variation in Europe (ICLaVE 8), Leipzig 2015. Amsterdam: Benjamins (to appear)

Haspelmath, Martin. 1998. Does grammaticalization need reanalysis? Studies in Language 22(2). 315-351.

Haspelmath, Martin. 1999. Why is grammaticalization irreversible? Linguistics 37(6). 10431068.

Haspelmath, Martin. 2000. The relevance of extravagance: A reply to Bart Geurts. Linguistics 38(4). 789-798.

Haspelmath, Martin. 2008. Parametric versus functional explanations of syntactic universals. In Theresa Biberauer (ed.), The limits of syntactic variation. Amsterdam: Benjamins.

Haspelmath, Martin. 2009. An empirical test of the Agglutination Hypothesis. In Sergio Scalise, Elisabetta Magni \& Antonietta Bisetto (eds.), Universals of language today, 13-29. Dordrecht: Springer.

Haspelmath, Martin. 2011a. The indeterminacy of word segmentation and the nature of morphology and syntax. Folia Linguistica 45(1). 31-80.

Haspelmath, Martin. 2011b. The gradual coalescence into "words" in grammaticalization. In Heiko Narrog \& Bernd Heine (eds.), The Oxford bandbook of grammaticalization, 342355. Oxford: Oxford University Press.

Haspelmath, Martin. 2015a. Defining vs. diagnosing linguistics categories: A case study of clitic phenomena. In Joanna Błaszczak, Dorota Klimek-Jankowska \& Krzysztof Migdalski 
(eds.), How categorical are categories? New approaches to the old questions of noun, verb and adjective, 273-303. Berlin: De Gruyter Mouton.

Haspelmath, Martin. 2015b. A grammatical overview of Egyptian and Coptic. In Eitan Grossman, Martin Haspelmath \& Tonio Sebastian Richter (eds.), Egyptian-Coptic linguistics in typological perspective, 103-143. Berlin: De Gruyter Mouton.

Haspelmath, Martin. 2017. Explaining alienability contrasts in adpossessive constructions: Predictability vs. iconicity. (under review, Glossa).

Heine, Bernd \& Tania Kuteva. 2005. Language contact and grammatical change. Cambridge: Cambridge University Press.

Heine, Bernd. 2017. Grammaticalization in Africa: Two contrasting hypotheses. In this volume.

Hintze, Fritz. Die Haupttendenzen der ägyptischen Sprachentwicklung. Zeitschrift für Phonetik und Allgemeine Sprachwissenschaft 1(3). 85-108.

Hock, Hans Henrich \& Brian D Joseph. 1996. Language history, language change, and language relationship: An introduction to historical and comparative linguistics. Berlin: Mouton de Gruyter.

Hodge, Carleton T. 1970. The linguistic cycle. Language Sciences 13(7). 1-7.

Horne, Kibbey M. 1966. Language typology: 19th and 20th century views. Washington: Georgetown University Press.

Horne, Kibbey M. 1970. Language typology: 19th and 20th century views. Washington: Georgetown University Press.

Humboldt, Wilhelm von. 1822. Über das Entstehen der grammatischen Formen und ihren Einfluss auf die Ideenentwicklung. Abhandlungen der Akademie der Wissenschaften zu Berlin. 31-63.

Hyman, Larry M. 2011. The Macro-Sudan belt and Niger-Congo reconstruction. Language Dynamics and Change 1(1). 3-49.

Igartua, Iván. 2015. From cumulative to separative exponence in inflection: Reversing the morphological cycle. Language 91(3). 676-722.

Jacob, Daniel. 1990. Markierung von Aktantenfunktionen und "Prädetermination" im Französischen: Ein Beitrag zur Neuinterpretation morphosyntaktischer Strukturen in der französischen Umgangssprache. Tübingen: Niemeyer.

Jespersen, Otto. 1894. Progress in language with special reference to English. New edition. Amsterdam/Philadelphia: Benjamins

Jespersen, Otto. 1922. Language: Its nature, origin and development. London: Allen \& Unwin.

Keller, Rudi. 1994. On language change: the invisible band in language. New York: Routledge.

Kiparsky, Paul \& Cleo Condoravdi. 2006. Tracking Jespersen's cycle. Proceedings of the 2nd International Conference of Modern Greek dialects and linguistic theory, 172-197.

Koptjevskaja-Tamm, Maria. 1996. Possessive noun phrases in Maltese: Alienability, iconicity and grammaticalization. Rivista di Linguistica 8(1). 245-274.

Lehmann, Christian. 2015. Thoughts on grammaticalization. Berlin: Language Science Press. (http://langsci-press.org/catalog/book/88)

Lehmann, Christian. 2017. Grammaticalization in Bopp. Veleia 33. (to appear).

Lüdtke, Helmut. 1980. Auf dem Weg zu einer Theorie des Sprachwandels. In Helmut Lüdtke (ed.), Kommunikationstheoretische Grundlagen des Sprachwandels. Berlin: de Gruyter.

Lüdtke, Helmut. 1986. Esquisse d'une théorie du changement langagier. La linguistique 22(1). 3-46.

McMahon, April M. S. 1994. Understanding language change. Cambridge: Cambridge University Press.

McWhorter, John H. 2007. Language interrupted: Signs of non-native acquisition in standard language grammars. Oxford: Oxford University Press.

Meillet, Antoine. 1912. L'évolution des formes grammaticales. 
Michaelis, Susanne Maria \& Martin Haspelmath. 2017. Grammaticalization in creole languages: Accelerated functionalization and semantic imitation. (a volume on grammaticalization).

Miller, Philip H. 1992. Clitics and constituents in phrase structure grammar. New York: Garland.

Nichols, Johanna. 1996. The comparative method as heuristic. In Mark Durie \& Malcolm Ross (eds.), The comparative method reviewed: Regularity and irregularity in language change, 3971. Oxford: Oxford University Press.

Plank, Frans. 1986. Paradigm size, morphological typology, and universal economy. Folia Linguistica 20(1-2). 29-48.

Ramat, Paolo. 2011. The (early) history of linguistic typology. In Jae Jung Song (ed.), The Oxford handbook of linguistic typology, 9-24. Oxford: Oxford University Press.

Reintges, Chris. 2013. Sapirian 'drift' towards analyticity and long-term morphosyntactic change in Ancient Egyptian. In: Kikusawa, Ritsuko \& Lawrence A. Reid (eds). 2013. Historical linguistics 2011: Selected papers from the 20th International Conference on Historical Linguistics, Osaka, 25-30 July 2011, 289-328. Amsterdam: John Benjamins.

Sapir, Edward. 1921. Language: An introduction to the study of speech. New York: Harcourt, Brace $\&$ Co.

Schwegler, Armin. 1990. Analyticity and syntheticity: A diacbronic perspective with special reference to Romance languages. Berlin: Mouton de Gruyter.

Siegel, Jeff, Benedikt Szmrecsanyi \& Bernd Kortmann. 2014. Measuring analyticity and syntheticity in creoles. Journal of Pidgin and Creole Languages 29(1). 49-85.

Stolz, Thomas. 1991. Agglutinationstheorie und Grammatikalisierungsforschung: Einige alte und neue Gedanken zur Entstehung von gebundener Morphologie. Zeitschrift für Phonetik, Sprachwissenschaft und Kommunikationsforschung 44(3). 325-338.

Weinrich, Harald. 1963. Ist das Französische eine analytische oder synthetische Sprache? Lebende Sprachen 8(2). 52-55.

Zide, Norman H. \& Gregory D.S. Anderson. 2001. The Proto-Munda verb: some connections with Mon-Khmer. In B. Rao \& K.V. Subbarao (eds.), Yearbook of South Asian Linguistics, 517-540. Delhi: Sage Press. 